\title{
Euphausiids (Crustacea: Euphausiacea) from a hotspot of marine biodiversity, Isla del Coco, Costa Rica, Eastern Tropical Pacific
}

\author{
Juan Carlos Azofeifa-Solano ${ }^{1}$, Marco Corrales-Ugalde ${ }^{2}$, Iván Castellanos-Osorio ${ }^{3}$ \& \\ Álvaro Morales-Ramírez ${ }^{1,4}$ \\ 1. Escuela de Biología, Universidad de Costa Rica, San Pedro, 11501-2060 San José, Costa Rica; \\ eazofeifa2@gmail.com, juan.azofeifa@ucr.ac.cr \\ 2. Oregon Institute of Marine Biology, University of Oregon, Eugene, OR, 97403 USA; mcugalde88@gmail.com \\ 3. El Colegio de la Frontera Sur, Unidad Chetumal. Av. Centenario km 5.5, Apdo. Postal 424. C.P.77014, Chetumal, \\ Quintana Roo, México; ivancast@ecosur.mx \\ 4. Centro de Investigación en Ciencias del Mar y Limnología (CIMAR), Ciudad de la Investigación, Universidad de \\ Costa Rica, San Pedro, 11501-2060 San José, Costa Rica; alvaro.morales@ucr.ac.cr
}

Received 05-V-2015. Corrected 25-IX-2015. Accepted 15-X-2015.

\begin{abstract}
Euphausiids have been well studied in several regions of the Pacific Ocean; however, there is less information regarding euphausiids in Costa Rican waters. We analyzed euphausiid specimens collected around Isla del Coco National Park during 2011 and 2012. A total of 130 specimens were analyzed and 13 euphausiid species were identified, belonging to four genera and one family. An annotated list of species is presented, with photographs and details for their identification. All species found represent new records for waters around Isla del Coco in the Costa Rican Pacific. The most frequent species were Euphausia diomedeae, Euphausia distinguenda, Nematoscelis gracilis and Stylocheiron affine. Rev. Biol. Trop. 64 (Suppl. 1): S221-S230. Epub 2016 Febrary 01.
\end{abstract}

Key words: krill, holozooplankton, species composition, epipelagic zone, Costa Rica.

Euphausiids (also known as krill) are a group of shrimp-like holoplanktonic crustaceans that inhabit all oceans (Baker, Boden, \& Brinton, 1990; Everson, 2000). They are an important part of the energy transfer between trophic webs of marine ecosystems, being effective phytoplankton grazers and preyed upon by diverse organisms including large invertebrates, fishes, sea birds, seals and whales (Mauchline, \& Fisher, 1969; Takashi, 1983; Williams, 1985; Agersted, Nielsen, Munk, Vismann, \& Arendt, 2011). Their carcasses and fecal pellets transport organic matter to deep waters and sediments (Wheeler, 1967; Fowler, \& Small, 1972). Euphausiids may also affect the fisheries of other organisms, for example Pauly, Christensen, Dalsgaard, Froese \& Torres (1998) mentioned that overfishing of the Norway pout (Trisopetrus esmarkii), a krill predator, could lead to an increase of euphausiid abundance, which in turn prey on copepods, an important food source for other commercial fishes, such as cod and saithe. Recently, large-scale commercial krill fisheries have been developed in South Atlantic along the Antarctic Peninsula, off the Japanese coast, and off the coast of British Columbia (Nicol, \& Endo, 1997). Euphausiids have specific distributional patterns associated with distinct water masses, and thus are used as indicators of oceanographic environments (Brinton, 1981; 1996; Lavaniegos, Lara-Lara, \& Brinton, 1989; Lavaniegos, 1994).

The biogeography of euphausiids in the Pacific Ocean has been extensively described by Brinton (1962), and several aspects of 
their biology have been also studied in this region (Brinton, \& Townsend, 1980; 2003; Mauchline, \& Fisher, 1969; Mauchline, 1980; Everson, 2000; Letessier, Cox, \& Brierley, 2011). The Eastern Tropical Pacific (ETP) had been determined as a distinct biogeographic province (Spalding, Agostini, Rice, \& Grant, 2012). Fernández-Álamo \& Färber-Lorda (2006) reported euphausiids as a very wellstudied taxon in this region. The first records of euphausiids in the ETP were made by Ortmann (1894) and Hansen (1912). Later, Brinton $(1962 ; 1979)$ described in detail the distributional patterns of euphausiid species and their relation to oceanographic parameters. Recent studies have been conducted in the Mexican Central Pacific, which include descriptions of euphausiid distribution, abundance, biomass, biochemical composition, and effects of wind forcing, upwelling and downwelling systems, and climate-oceanographic phenomena such as El Niño on krill populations (López-Cortés, 1990; Färber-Lorda, Lavín, Zapatero, \& Robles, 1994; Färber-Lorda, Lavín, \& Guerrero-Ruiz, 2004; Färber-Lorda, Trasviña, \& Cortés-Verdín, 2010; Ambriz-Arreola, GómezGutiérrez, Franco-Gordo, Lavaniegos, \& Godínez-Domínguez, 2012; Gómez-Gutiérrez et al., 2014). The distribution of euphausiids had been also studied in the Colombian Pacific (López-Peralta, \& Medellín-Mora, 2010). In the Central American Pacific, there have been studies on crustacean larvae (including krill) (Sánchez-Maravilla, 1986), and diel vertical migrations of euphausiids (Sameoto, Guglielmo, \& Lewis, 1987).

Despite the extensive research on euphausiids from the ETP, there is less specific information regarding euphausiids in the Costa Rican Pacific and Isla del Coco (Castellanos, Suárez-Morales, \& Morales-Ramírez, 2009). It is important to fill the gaps on taxonomic and diversity knowledge in marine ecosystems to identify and understand the economic and ecological relevance that these organisms might have on several oceanic areas (Costello et al., 2010). Regional checklists of marine species are also important tools for recognizing and delimiting areas in need for protection (Hendrickx, \& Harvey, 1999). The present study is the first attempt to record the euphausiid species around Isla del Coco.

\section{MATERIALS AND METHODS}

Isla del Coco (also known as Cocos Island) is located in the ETP, and represents the core of the Isla del Coco Marine Conservation Area (Fig. 1), declared UNESCO World Heritage in 1997 and RAMSAR site in 1998 (Cortés, 2008). The island is located $\sim 500 \mathrm{~km}$ southwest of Cabo Blanco, Costa Rica, and it is the only exposed point of the Coco Cordillera (Castillo et al., 1988; Rojas, \& Alvarado, 2012). The waters around Isla del Coco are influenced by the seasonal movement of Inter-Tropical Convergence Zone (Broenkow, 1965; Alfaro, 2008), periodic El Niño events (Fiedler, \& Talley, 2006), and even the seasonal upwelling in the Gulf of Papagayo (Lizano, 2008). Physicochemical analyses from waters around Isla del Coco revealed influence from both coastal and oceanic waters (Acuña, García, Gómez, Vargas, \& Cortés, 2008).

In order to describe the zooplankton community from Isla del Coco, two oceanographic expeditions were carried out in March 2011 and June 2012 aboard the MV Argo and MV Undersea Hunter, respectively. For a more detailed explanation of the two oceanographic expeditions see Brenes et al. (2011) and Cortés et al. (2012). A total of 35 stations in March 2011 and 25 in June 2012 were sampled around Isla del Coco. In this paper we present results from eight of them (one from 2011 and seven from 2012) (Fig. 1).

During both oceanographic expeditions, zooplankton samples were collected using a standard General Oceanics net $(202 \mu \mathrm{m}$ mesh, $50 \mathrm{~cm}$ diameter, $1.5 \mathrm{~m}$ length) towed vertically from $100 \mathrm{~m}$ and $200 \mathrm{~m}$ deep to the surface in 2011 and 2012, respectively (Table 1). All the zooplankton samples were preserved in seawater with $4 \%$ formalin and transported to the Zooplankton Laboratory at CIMAR, UCR. Only adult euphausiid specimens were 


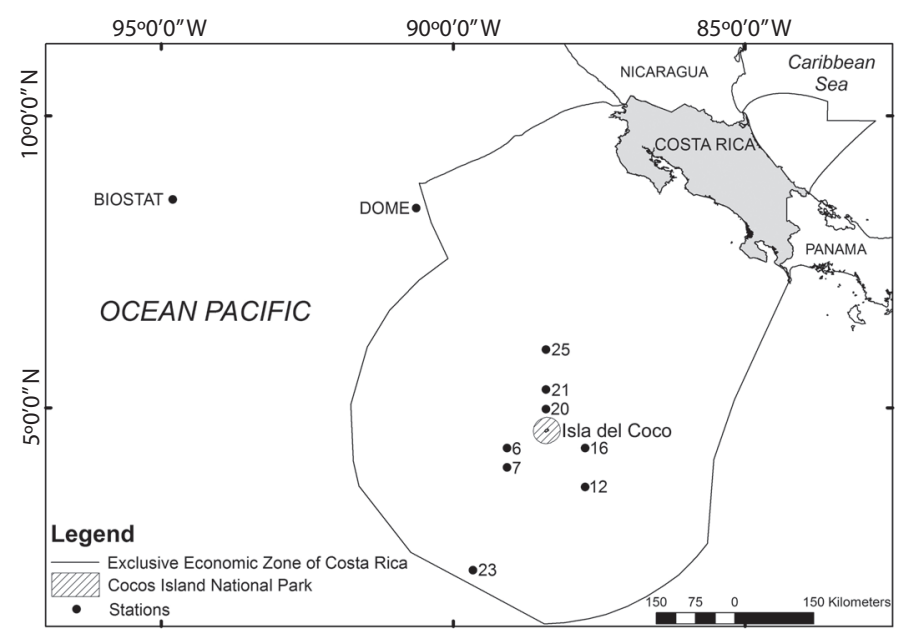

Fig. 1. Surveyed area and location of sampling stations of the present work in adjacent waters to Cocos Island, Costa Rica. BIOSTAT and DOME stations from Sameoto et al., 1987.

Fig. 1. Área de estudio y localización de las estaciones de muestreo en aguas adyacentes a la Isla del Coco, Costa Rica. Estaciones BIOSTAT y DOME de Sameoto et al., 1987.

TABLE 1

Date, time of collection, geographic coordinates and depth of sampling stations in adjacent waters to Cocos Island, Costa Rica

\section{CUADRO 1}

Fecha, hora de colecta, coordenadas geográficas y profundidad de las estaciones de muestreo en aguas adyacentes a la Isla del Coco, Costa Rica

\begin{tabular}{cccccc} 
Station & Date & Time of collection & Latitude & Longitude & Depth (m) \\
23 & $29 / 03 / 2011$ & $18: 44-20: 07$ & 3.0995 & -88.31035 & $0-100$ \\
6 & $08 / 06 / 2012$ & $20: 46-21: 40$ & 5.19252 & -87.72465 & $0-200$ \\
7 & $09 / 06 / 2012$ & $00: 33-01: 32$ & 4.8591 & -87.72538 & $0-200$ \\
12 & $09 / 06 / 2012$ & $23: 35-00: 35$ & 4.52662 & -86.3895 & $0-200$ \\
16 & $10 / 06 / 2012$ & $19: 27-20: 27$ & 5.19191 & -86.38947 & $0-200$ \\
20 & $11 / 06 / 2012$ & $19: 10-20: 20$ & 5.85736 & -87.05848 & $0-200$ \\
21 & $11 / 06 / 2012$ & $22: 58-23: 58$ & 6.19191 & -87.0587 & $0-200$ \\
25 & $12 / 06 / 2012$ & $18: 51-19: 50$ & 6.8774 & -87.0587 & $0-200$ \\
\hline
\end{tabular}

separated from the samples, counted and identified following Baker et al. (1990) and Brinton, Ohman, Townsend, Knight \& Bridgeman (2000). All the specimens were deposited in the crustacean collection at the Zoology Museum, University of Costa Rica (Museo de Zoología, Universidad de Costa Rica, MZUCR).

\section{RESULTS}

A total of 130 specimens were analyzed. The present study reports 13 krill species, distributed in four genera, all belonging to the family Euphausiidae (Table 2; Figs. 2, 3, 4). All the species are new records for Isla del Coco in the Costa Rican Pacific. The most frequent species were Euphausia distinguenda, Euphausia diomedeae, Nematoscelis gracilis and Stylocheiron affine, with more than 10 specimens.

\section{DISCUSSION}

The 13 euphausiid species found in Isla del Coco were previously recorded in the ETP 
TABLE 2

List of euphausiid species, number of specimens and sites of collection in waters around Isla del Coco, Costa Rica

CUADRO 2

Lista de especies de eufáusidos, número de especímenes y sitio de recolecta en aguas alrededor de la Isla del Coco, Costa Rica

\begin{tabular}{llll}
\multicolumn{1}{c}{ Species } & $\begin{array}{c}\text { Number of } \\
\text { specimens }\end{array}$ & \multicolumn{1}{c}{ Stations } & \multicolumn{1}{c}{ Catalog number } \\
\hline Euphausia diomedeae Ortmann, 1894 & 18 & $6,7,12,16,23$ & $3319-06,3339-07,3356-02,3358-01,3359-02$ \\
E. distinguenda Hansen, 1908 & 43 & $6,7,12,16,20,21,25$ & $3319-07,3320-02,3339-04,3355-05,3356-05,3357-04,3358-06$ \\
E. eximia Hansen, 1911 & 5 & 20,25 & $3355-03,3357-01$ \\
E. gibboides Ortmann, 1893 & 3 & 6,23 & $3319-023359-01$ \\
E. lamelligera Hansen, 1911 & 2 & 25 & $3355-04$ \\
E. tenera Hansen, 1905 & 4 & $6,7,16$ & $3319-08,3356-04,3358-03$ \\
Nematobrachion flexipes (Ortmann, 1893) & 6 & $6,16,21$ & $3319-01,3320-01,3358-02$ \\
Nematoscelis gracilis Hansen, 1910 & 23 & $6,7,12,16,20,25$ & $3319-05,3339-05,3355-02,3356-01,3357-02,3358-04$ \\
N. tenella G.O. Sars, 1883 & 1 & 12 & $3339-06$ \\
Stylocheiron affine Hansen, 1910 & 13 & $6,7,12,16,20,21,25$ & $3319-03,3320-03,3339-01,3355-01,3356-03,3357-05,3358-05$ \\
S. carinatum G.O. Sars, 1883 & 8 & $6,12,21$ & $3319-04,3339-02$ \\
S. longicorne G.O. Sars, 1883 & 3 & 20 & $3357-03$ \\
S. maximum Hansen, 1908 & 1 & 12 & $3339-03$ \\
\hline
\end{tabular}

and waters near Costa Rica by the "Shellback" expedition in 1952 (Brinton, 1962). Sameoto et al. (1987) reported 17 euphausiid species near the Costa Rica Dome outside the Economic Exclusive Zone of Costa Rica (Fig. 1). The higher species richness reported for the Costa Rica dome is probably related with the depth range sampling (0-1000 $\mathrm{m}$ depth) and technique (multiple opening and closing net) (Sameoto et al., 1987), while this study only analyzed samples from $200 \mathrm{~m}$ and $100 \mathrm{~m}$ depth using a standard net. Only $65 \%$ of euphausiid species found in Costa Rica Dome are reported for Isla del Coco. Moreover, Euphausia tenera and Nematoscelis tenella were not reported by Sameoto et al. (1987) from the Dome station; however, both species were collected in the BIOSTAT station (off Central American coast). The euphausiid species assemblage of Isla del Coco should be determined by the particular oceanographic dynamics surrounding the island (Broenkow, 1965; Fiedler, \& Talley, 2006; Acuña et al., 2008; Alfaro, 2008; Lizano, 2008).
Brinton (1979) grouped the euphausiids from ETP by biogeographic and hydrographic affinities. The non-migrating warm cosmopolites are N. tenella, S. affine, Stylocheiron carinatum, Stylocheiron longicorne and Stylocheiron maximum. The species that proliferate in the north and south margins of ETP are Euphausia eximia, Nematobrachion flexipes and Euphausia gibboides. These species are found in the low oxygen layer, but are more abundant in its margins. The equatorial endemic species are adapted to migrate into the low oxygen layer. This group includes $E$. diomedeae, E. distinguenda, Euphausia lamelligera and $N$. gracilis. Finally, E. tenera is a widely distributed species, thus it was not included in any group by Brinton (1979). We emphasize that the most common species in the present study were mainly from the equatorial endemics group (E. distinguenda, E. diomedeae and $N$. gracilis), and $S$. affine, a non-migrating warm cosmopolite species that can also be found through the low oxygen layer.

Isla del Coco hosts a high marine biodiversity (Cortés, 2012), which might also apply for 

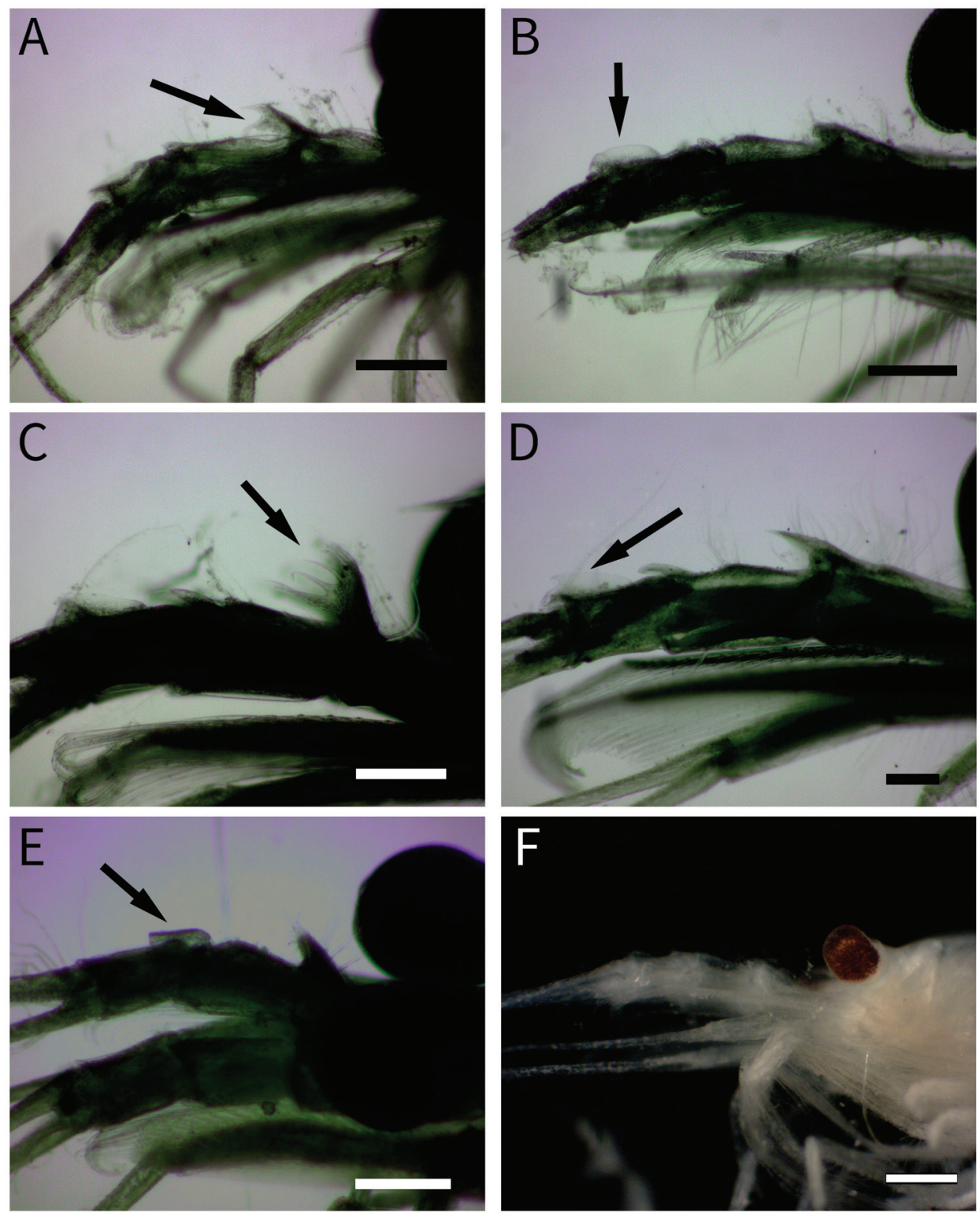

Fig. 2. (A) Euphausia diomedeae, bifid lappet in first antennular segment; (B) Euphausia distinguenda, conspicuous keel in the third antennular segment with a little denticule; (C) Euphausia eximia, pectinate lappet in the first antennular segment; (D) Euphausia gibboides, conspicuous keel in the third antennular segment pointed forward; (E) Euphausia lamelligera, movable plate in the second antennular segment; (F) Euphausia tenera, third antenular segment without a keel, eyes are little and oval. Scale in A, B, C, D, E, and $\mathrm{F}=500 \mu \mathrm{m}$.

Fig. 2. (A) Euphausia diomedeae, proceso antenular bífido en el primer segmento antenular; (B) Euphausia distinguenda, quilla conspicua en el tercer segmento antenular; (C) Euphausia eximia, proceso antenular pectinado en el primer segmento antenular; (D) Euphausia gibboides, quilla conspicua en el tercer segmento antenular apuntando hacia adelante; (E) Euphausia lamelligera, placa móvil en el segundo segmento antenular; (F) Euphausia tenera, el tercer segmento antenular sin quilla, ojos pequeños y ovales. Escala en A, B, C, D, E y F=500 $\mu \mathrm{m}$. 

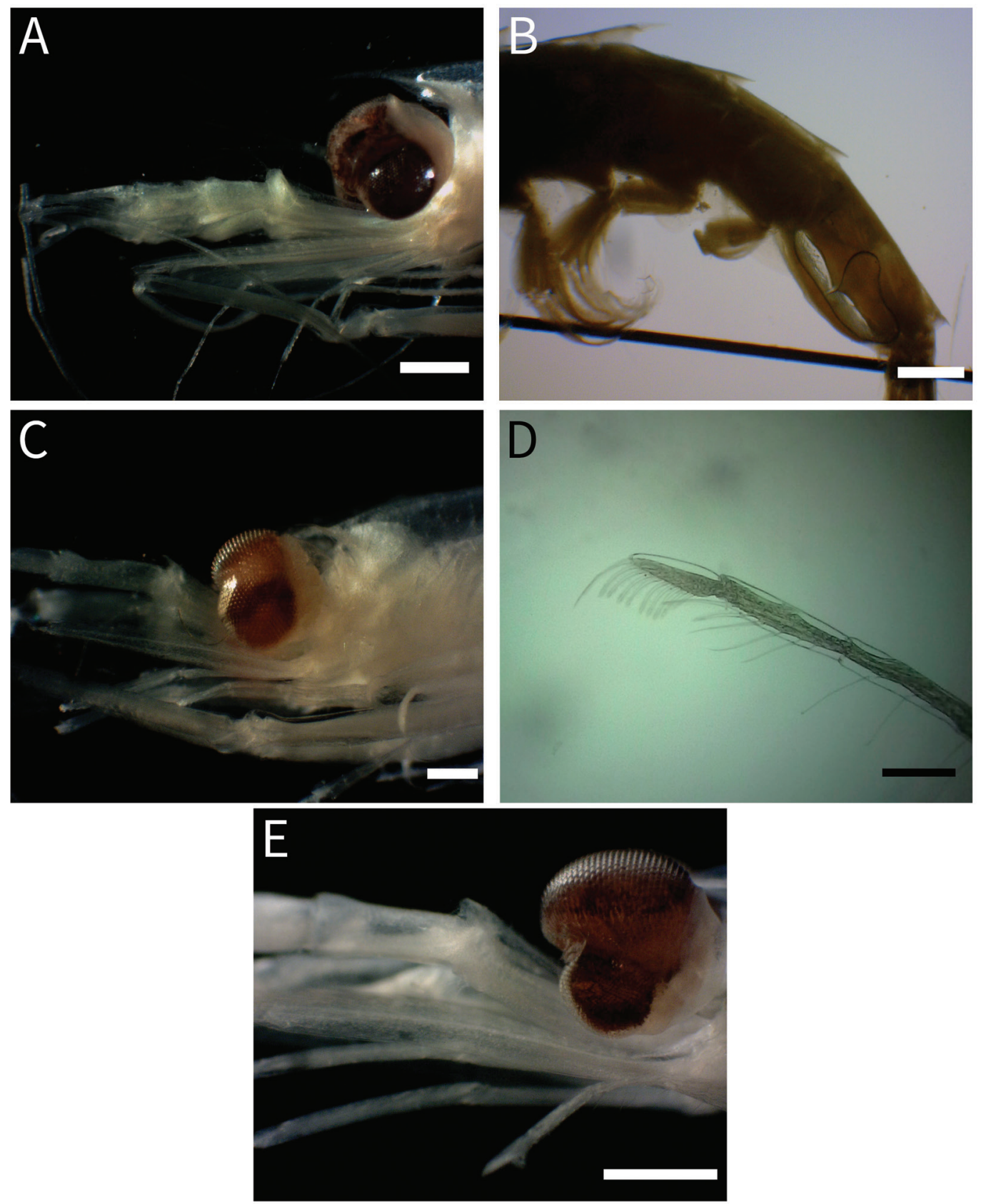

Fig. 3. (A) Nematobrachion flexipes, rounded lappet in the first antennular segment; (B) N. flexipes, mid-dorsal spines in the abdominal segments 3-6; (C) Nematoscelis gracilis, size of upper lobe of the eye very similar to lower lobe; (D) N. gracilis, dactylus and propodus of the first thoracic leg; (E) Nematoscelis tenella, upper lobe of the eye bigger than the lower lobe. Scale in $\mathrm{A}, \mathrm{C}, \mathrm{D}, \mathrm{E}$ and $\mathrm{F}=500 \mu \mathrm{m}$. Scale in $\mathrm{B}=1 \mathrm{~mm}$.

Fig. 3. (A) Nematobrachion flexipes, proceso antenular redondeado en el primer segmento antenular; (B) N. flexipes, espinas medio-dorsales en los segmentos abdominales 3-6; (C) Nematoscelis gracilis, tamaño del lóbulo superior del ojo similar al lóbulo inferior; (D) N. gracilis, dáctilo y propodo de la primera pata torácica; (E) Nematoscelis tenella, lóbulo superior del ojo mucho más grande que el lóbulo inferior. Escala en A, C, D, E y F=500 $\mu \mathrm{m}$. Escala en B=1 mm. 

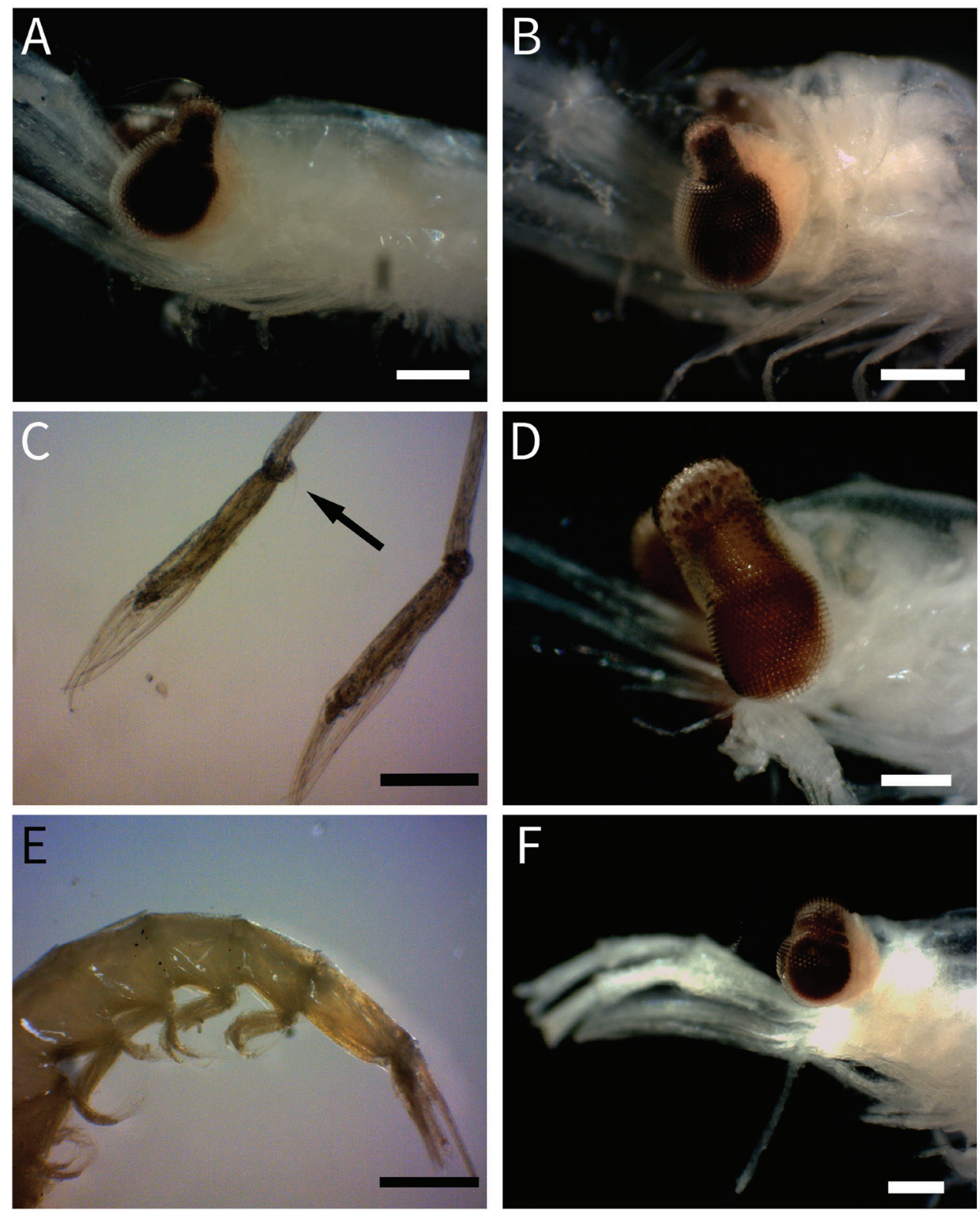

Fig. 4. (A) Stylocheiron affine, upper ocular lobe with 4-8 enlarged crystallines in transversal row; (B) Stylocheiron carinatum, upper ocular lobe short and narrow, with parallel anterior and posterior margins that sharply join in the lower lobe; (C) S. carinatum, the posterior margin of the propodus in the third thoracic leg bears a tubercule with a setae; (D) Stylocheiron longicorne, upper ocular lobe with 19 enlarged crystallines in transversal row; (E) S. longicorne, abdominal segments; (F) Stylocheiron maximum, eyes whit a sharp constriction between the upper and lower lobes, the upper lobe is smaller than the lower. Scale in $\mathrm{A}, \mathrm{B}, \mathrm{C}$ and $\mathrm{D}=500 \mu \mathrm{m}$. Scale in $\mathrm{E}$ and $\mathrm{F}=1 \mathrm{~mm}$.

Fig. 4. (A) Stylocheiron affine, lóbulo superior con 4-8 cristalinos alargados en línea transversal; (B) Stylocheiron carinatum, lóbulo ocular superior corto y delgado, con los márgenes que se unen abruptamente al lóbulo inferior; (C) S. carinatum, el margen posterior del propodo de la tercer pata torácica porta un tubérculo con una seta; (D) Stylocheiron longicorne, lóbulo ocular superior con 19 cristalinos alargados en línea transversal; (E) S. longicorne, segmentos abdominales; (F) Stylocheiron maximum, ojos con una constricción marcada en medio de los lóbulo superior e inferior, el lóbulo superior es más pequeño que el inferior. Escala en $A, B, C$ y $D=500 \mu \mathrm{m}$. Escala en $E$ y $F=1 \mathrm{~mm}$. 
euphausiids. The waters around the island host $22 \%$ of the 59 species reported for the Pacific Ocean (Brinton, 1962; 1979) and $55 \%$ (20 species) for Central American Pacific waters (Castellanos et al., 2009). Compared with studies from the Central Pacific coast of Mexico (Färber-Lorda et al., 1994; 2010; Ambriz-Arreola et al., 2012) that have reported ten or less species, this study reports 13 species with less sampling effort. Here we present useful pictures that may help in identification of specimens from Costa Rican Pacific. The specimens analyzed in the present study were the first euphausiids deposited at the crustacean collection of the Museum of Zoology, University of Costa Rica.

Although this is the first effort to record the euphausiid diversity from Isla del Coco, samples from deeper waters are needed to found deep-water distributed species reported for Central American waters (Brinton, 1962; 1979; Sameoto et al., 1987; Castellanos et al., 2009). Moreover, information regarding the vertical distribution, ecological relationships, and temporal patterns of species composition is still needed to understand the dynamics of krill, which might be an important component for ecosystems and fisheries in Costa Rican waters. Therefore, our future goal is to assess the euphausiid community diversity and ecology in the Costa Rican Pacific waters, and we are currently preparing an ecologically focused work.

\section{ACKNOWLEDGMENTS}

We are very grateful with Octavio Esquivel and Fabiola Jiménez who collected the zooplankton samples and Keats Conley for her linguistic revision of the manuscript. This research was financially supported by the Consejo Nacional de Rectores (CONARE) through FEES fund and to Vicerrectoría de Investigación of the Universidad de Costa Rica through the projects $808-\mathrm{B} 0-654$ and 808 -B0060 . We are greatly thankful to five anonymous reviewers that helped improve the quality of this manuscript.

\section{RESUMEN}

Eufáusidos (Crustacea: Euphausiacea) de un punto caliente de biodiversidad marina, Isla del Coco, Costa Rica, Pacífico Tropical Oriental. Los eufáusidos han sido ampliamente estudiados en el Océano Pacífico, sin embargo existe poca información respecto a los eufáusidos que habitan aguas costarricenses. Analizamos 130 especímenes de eufáusidos provenientes de muestras de zooplancton recolectadas alrededor de la Isla del Coco del 2011 y 2012. Identificamos 13 especies pertenecientes a cuatro géneros y una familia. Se presenta un listado de especies y fotografías con detalles que facilitan su identificación. Todas las especies encontradas representan nuevos informes para aguas de la Isla del Coco en el Pacífico costarricense. Las especies más frecuentes fueron Euphausia distinguenda, Nematoscelis gracilis, Euphausia diomedeae y Stylocheiron affine.

Palabras clave: kril, Pacífico Tropical Oriental, composición de especies, holozooplancton, zona epipelágica.

\section{REFERENCES}

Acuña, J., García, J., Gómez, E., Vargas, J. A., \& Cortés, J. (2008). Parámetros físico-químicos en aguas costeras de la Isla del Coco, Costa Rica (2001-2007). Revista de Biología Tropical, 56(Supplement 2), 49-56.

Agersted, M. A., Nielsen, T. G., Munk, P., Vismann, B., \& Arendt, K. E. (2011). The functional biology and trophic role of krill (Thysanoessa raschii) in a Greenlandic fjord. Marine Biology, 158(6), 1387-1402.

Alfaro, E. J. (2008). Ciclo diario y anual de variables troposféricas y oceánicas en la Isla del Coco, Costa Rica. Revista de Biología Tropical(Supplement 2), 56, 19-29.

Ambriz-Arreola, I., Gómez-Gutiérrez, J., Franco-Gordo, M. C, Lavaniegos, B. E., \& Godínez-Domínguez, E. (2012). Influence of coastal upwelling-downwelling variability on tropical euphausiid abundance and community structure in the inshore Mexican central Pacific. Marine Ecology Progress Series, 451, 119-136.

Baker, A. de C., Boden, B. P., \& Brinton, E. (1990). A Practical Guide to the Euphausiids of the World. London, England: Natural History Museum Publications.

Brenes, C., Lizano, O., Acuña, J., Alfaro, E., Márquez, A., Ruiz, E., Delgado, C., Corrales, M., Esquivel, O., Salazar, J. P., \& Quesada, R. (2011). Informe de la expedición científica UCR-UNA-COCO-III. Campaña Oceanográfica Corredor Costa Rica-Isla del Coco. Proyecto: Interacción océano-atmósfera y la biodiversidad marina del Parque Nacional Isla del Coco, Costa Rica. 26 Marzo - 03 Abril 2011. 
San José, Costa Rica: Universidad de Costa RicaUniversidad Nacional, Costa Rica.

Brinton, E. (1962). The distribution of Pacific euphausiids. Bulletin of the Scripps Institution of Oceanography, $8,51-270$.

Brinton, E. (1979). Parameters relating to the distributions of planktonic organism, especially Euphausiids in the eastern tropical Pacific. Progress in Oceanography, $8,125-189$

Brinton, E. (1981). Euphausiid distributions in the California current during the warm winter-spring of 1977-78, in the context of a 1949-1966 time series. California Cooperative Oceanic Fisheries Investigations Reports, 22, 135-154.

Brinton, E. (1996). Euphausiacea. In R. Gasca \& E. Suárez-Morales (Eds.), Introducción al Estudio del Zooplancton Marino (pp. 297-342). Chetumal, Mexico: ECOSUR/CONACYT.

Brinton, E., \& Townsend, A. W. (1980). Euphausiids in the Gulf of California, the 1957 cruises. California Cooperative Oceanic Fisheries Investigations Reports, 21, 211-235.

Brinton, E., \& Townsend, A. (2003). Decadal variability in abundances of the dominant euphausiid species in southern sector of the California Current. Deep-Sea Research II, 50, 2449-2472.

Brinton, E., Ohman, M., Townsend, A. W., Knight, M. D., \& Bridgeman, A. L. (2000). Euphausiids of the World. World Biodiversity Database CD-ROM Series. Berlin, Germany: Springer Verlag.

Broenkow, W. W. (1965). The distribution of nutrients in the Costa Rica Dome in the Eastern Tropical Pacific Ocean. Limnology and Oceanography, 10, 40-52.

Castellanos, I., Suárez-Morales, E., \& Moráles-Ramírez, A. (2009). Euphausiids. In I. S. Wehrtmann \& J. Cortés (Eds.), Marine Biodiversity of Costa Rica, Central America (pp. 199-207). Berlin, Germany: Springer Science + Business Media B.V.

Castillo, R., Batista, R., Vanco, D., Malavassi, E., Barquero, J., \& Fernández, E. (1988). Anomalously young volcanoes on hot spot traces: I. Geology and petrology of Cocos Island. Geological Society of America Bulletin, 100, 1400-1414.

Cortés, J. (2008). History of marine research at Cocos Island, Costa Rica. Revista de Biología Tropical, 56(Supplement 2), 1-18.

Cortés, J. (2012). Marine biodiversity of an Eastern Tropical Pacific oceanic island, Isla del Coco, Costa Rica. Revista de Biología Tropical, 60(Supplement 3), 131-185.

Cortés, J., Morales, A., Lizano, O., Alfaro, E., Moreno, M. L., Sibaja, J., Gómez, E., Gavlas, A. M., García, J., Ruiz, E., Nivia, J., Murillo, G., \& Salazar, A. (2012). Informe de la expedición científica
UCR-UNA-COCO-IV. Proyecto: Interacción océanoatmósfera y la biodiversidad marina del Parque Nacional Isla del Coco, Costa Rica. 30 Junio - 10 Julio 2011. San José, Costa Rica: Universidad de Costa Rica-Universidad Nacional, Costa Rica.

Costello, M. J., Coll, M., Danovaro, R., Halpin, P., Ojaveer, H., \& Miloslavic, P. (2010). A census of marine biodiversity knowledge, resources, and future challenges. PLoS ONE, 5(8), e12110. doi:10.1371/journal. pone. 0012110

Everson, I. (2000). Introducing Krill. In I. Everson (Ed.), Krill: Biology, Ecology and Fisheries (pp. 1-7). Oxford, United Kingdom: Fish and Aquatic Resources, Series 6. Blackwell Science.

Färber-Lorda, J., Lavín, M. F., \& Guerrero-Ruiz, M. A. (2004). Effects of wind forcing on the trophic conditions, zooplankton biomass and krill biochemical composition in the Gulf of Tehuantepec. Deep-Sea Research II, 51, 601-614.

Färber-Lorda, J., Lavín, M. F., Zapatero, M. A., \& Robles, J. M. (1994). Distribution and abundance of euphausiids in the Gulf of Tehuantepec during wind forcing. Deep-Sea Research I, 41, 359-367.

Färber-Lorda, J., Trasviña, A., \& Cortés-Verdín, P. (2010). Summer distribution of euphausiids in the entrance of the Sea of Cortés in relation to hydrography. DeepSea Research II, 57, 631-641.

Fernández-Álamo, M. A., \& Färber-Lorda, J. (2006). Zooplankton and the oceanography of the Eastern Tropical Pacific: a review. Progress in Oceanography, 69, 318-359.

Fiedler, P. C., \& Talley, L. D. (2006). Hydrography of the eastern tropical Pacific: A review. Progress in Oceanography, 69, 143-180.

Fowler, S. W., \& Small, L. F. (1972). Sinking rates of euphausiid fecal pellets. Limnology and Oceanography, 17(2), 293-296.

Gómez-Gutiérrez, J., Funes-Rodríguez, R., Arroyo-Ramírez, K., Sánchez-Ortíz, C. A., Beltrán-Castro, J. R., Hernández-Trujillo, S., Palomares-García, R., Aburto-Oropeza, O., \& Ezcurra, E. (2014). Oceanographic mechanisms that possibly explain dominance of neritic tropical zooplankton species assemblages around the Islas Marías Archipelago, Mexico. Latin American Journal of Aquatic Research, 42, 1009-1034.

Hansen, H. J. (1912). Reports on the scientific results of the expedition to the Tropical Pacific, in charge of Alexander Agassiz, by the U.S. Fish Comission Steamer "Albatross", from August, 1899, to March, 1900, Commander Jefferson F. Moser, U.S.N., Commanding. XVI. Reports on the scientific results of the expedition to the Eastern Tropical Pacific, in charge of Alexander Agassiz, by the U.S. Fish commission steamer "Albatross", from October, 1904, to March, 1905, Lieut.-Commander L. M. Garrett, U.S.N., 
Commanding. XXVII. The Schizopoda. Memoirs of the Museum of Comparative Zoology, 35, 59-114.

Hendrickx, M. E., \& Harvey, A. W. (1999). Checklist of anomuran crabs (Crustacea: Decapoda) from the Eastern Tropical Pacific. Belgian Journal of Zoology, 129, 363-389.

Lavaniegos, B. E. (1994). Dispersion and development patterns in larvae of Nyctiphanes simplex (Euphausiacea) in the upwelling region off Baja California. Marine Ecology-Progress Series, 106, 207-225.

Lavaniegos-Espejo, B. E., Lara-Lara, J. R., \& Brinton, E. (1989). Effects of the 1982-83 El Niño event on the euphausiid populations of the Gulf of California. California Cooperative Oceanic Fisheries Investigations Reports, 30, 73-87.

Letessier, T. B., Cox, M. J., \& Brierley, A. S. (2011). Drivers of variability in euphausiid species abundance throughout the Pacific Ocean. Journal of Plankton Research, 33(9), 1342-1357.

Lizano, O. G. (2008). Dinámica de aguas alrededor de la Isla del Coco, Costa Rica. Revista de Biología Tropical, 56(Supplement 2), 31-48.

López-Cortés, D. J. (1990). Distribución de la familia Euphausiidae (Euphausiacea: Crustacea) en el Golfo de Tehuantepec, México. Revista de Biología Tropical, 38, 21-28.

López-Peralta, R. H., \& Medellín-Mora, J. (2010). Distribución de eufausiáceos (Crustacea: Malacostraca) en el Pacífico Colombiano durante el periodo 02 a 27 de septiembre de 2005. Revista Facultad de Ciencias Básicas, 6(2), 240-255.

Mauchline, J. (1980). The biology of euphausiids. Advances in Marine Biology, 18, 73-623.

Mauchline, J., \& Fisher, L. R. (1969). The biology of euphausiids. Advances in Marine Biology, 7, 1-454.

Nicol, S., \& Endo, Y. (1997). Krill Fisheries of the World. Rome, Italy: FAO.
Ortmann, A. E. (1894). Reports on the dredging operations off the west coast of Central America to the Galapagos, to the west coast of Mexico, and the Gulf of California, in charge of Alexander Agassiz, carried on by the U.S. Fish. Commission steamer "Albatross" during 1891, Lieut. Commander Z. L. Tanner, U.S.N., Commanding. XIV. The pelagic schizopoda. Bulletin of the Museum of Comparative Zoology, 25, 99-111.

Pauly, D., Christensen, V., Dalsgaard, J., Froese, R., \& Torres, F. Jr. (1998). Fishing down marine food webs. Science, 279, 860-863.

Rojas, W., \& Alvarado, G. E. (2012). Geología y contexto geotectónico de la Isla del Coco y la zona marítima frente al Pacífico central de Costa Rica. Revista de Biología Tropical, 60(Supplement 3), 15-32.

Sameoto, D., Guglielmo, J., \& Lewis, M. K. (1987). Day/ night vertical distribution of euphausiids in the Eastern Tropical Pacific. Marine Biology, 96(2), 235-245.

Sánchez-Maravilla, E. E. (1986). Distribución y abundancia de las larvas de crustáceos en la región del Domo de Costa Rica (Licenciatura Thesis). Universidad Nacional Autónoma de México, México D.F., México.

Spalding, M. D., Agostini, V. N., Rice, J., \& Grant, S. M. (2012). Pelagic provinces of the world: a biogeographic classification of the world's surface pelagic waters. Oceans \& Coastal Management, 60, 19-30.

Takashi, M. (1983). Trophic ecology of demersal fish community north of the South Shetland Islands, with notes on the ecological role of the krill. Memoirs of National Institute of Polar Research, 27, 183-192.

Wheeler, E. H. Jr. (1967). Copepod detritus in the deep sea. Limnology and Oceanography, 12(4), 697-702.

Williams, R. (1985). Trophic relationships between pelagic fish and euphausiids in Antarctic waters. In W. R. Siegfried, P. R. Condy \& R. M. Laws (Eds.), Antarctic Nutrient Cycles and Food Webs (pp. 452-459). Berlin, Germany: Springer Berlin Heidelberg. 